\title{
Industrial culture as an asset, barrier and creative challenge for restructuring of old industrial cities: case study of Ostrava (Czechia)
}

\author{
Vojtěch Bosák $^{1, \otimes}-$ Alexandr Nováček ${ }^{1}-$ Ondřej Slach $^{1}$ \\ ${ }^{1}$ Department of Human Geography and Regional Development, Faculty of Science, University of Ostrava, Ostrava, Czech Republic \\ ${ }^{\otimes}$ 16235@student.osu.cz
}

\begin{abstract}
Old industrial cities abound with extensive infrastructures, which however no longer suit the economic purposes, for which they were originally built. However either their demolition or a complete rebuilding of new is often not a viable option, and thus the issue of their smart reuse emerged in urban studies. In this paper we combine literature on restructuring, brownfields, and industrial heritage to assess their significance both as a barrier and asset for future urban development. The main aim is to provide municipalities with an overview of the range of their possible reuses, and problems they might face in doing so. Furthermore, the selected examples show that contemplating new use should be guided by assessment of intrinsic features of the structures on one hand, and by general global trends on other. This new combination of the two might render the new use competitive. For this sake a case study of the old industrial city of Ostrava is employed, as this issue has been particularly pronounced given the city's strong historical specialisation in heavy industry.
\end{abstract}

Keywords

Industrial heritage,

Old industrial city,

Restructuring,

New combination,

Ostrava

Received:

10 May 2018

Received in revised form:

11 June 2018

Accepted:

14 June 2018

\section{Highlights for public administration, management and planning:}

- Industrial heritage is an important local asset in old industrial cities, but if not utilised it can represent a barrier for restructuring.

- For competitiveness of industrial heritage reuse, it is advisable to follow general global trends in such areas as demography (housing) and society (lifestyle, social services).

- The case study of the old industrial city of Ostrava provide impetus for imaginative thinking of municipalities in other cities that wish to utilise their industrial heritage.

\section{Introduction}

The aim of the paper is to comprehend the issue of industrial heritage in its complexity, departing from the rather nostalgic notions that surround it (Jigoria-Oprea \& Popa 2017), and hinder its utilisation for present needs. In this regard we believe that the line of literature dealing with brownfields can enrich debate on industrial heritage through realistically pointing to, especially, constraints for the new use. At the same time, we assume that in order for the new use of industrial heritage to be 'competitive' it must comply with current global trends (Hospers 2002,
2005; Koutský et al. 2011). Furthermore, we understand industrial heritage as an ambiguous feature that is an asset and barrier at the same time, and which aspect prevails is dependent on a constellation of actors (Rautenberg 2012) and their imagination. While Harfst (2015) classified industrial heritage in two basic groups of tangible and intangible features, we explore, besides the tangible features themselves, the middle ground between the two, that is meanings, symbols, identities and images attached to tangible built structures (see Helbrecht 2004). The paper concentrates on remnants of the industrial past in the built environment that is not only on former buildings of production, but also supporting infrastructures 
connected to energy supply, transportation, waste treatment and amenities for workers, while impacts on urbanistic structure of the whole city are also included. To illustrate the range of issues connected to utilisation of industrial heritage, a case study of old industrial city of Ostrava is employed.

\section{Restructuring in old industrial cities}

Since old industrial cities historically evolved according to the needs of dominant, capital-intensive industries, they abound with narrowly focused structures (e.g. railways, land use), whose change is, however, time and capital-consuming (see e.g. Hamm \& Wienert 1990; Kilper 1999). Thus, these structures hold back restructuring, or in other words, adaptation to new conditions, and creation of new, growing industries (Grabow \& HollbachGrömig 1995; Martin 2010). A classic example of "backwash effect" of these structures is related to mixing of incompatible land-uses (e.g. neighbouring air-polluting industrial plants and residential areas), which does not impact only quality of life of inhabitants, but also thwarts attracting and maintaining highly skilled labour, which may otherwise help to diversify the economic base and reduce labour market mismatch (Power et al. 2010; Agueda 2014). However, abandonment of cities that were once the engines of national economies (Sucháček \& Herot 2015; Ženka et al. 2017) would pay them injustice. As the structures are thought of as the main local culprits of industrial decline and, at the same time, it is not easy to change them, Siebel et al. (2001) recommended their smart reuse. Whether this effort takes shape as a comprehensive public sector strategy on a regional scale (Agueda 2014) or as more piecemeal interventions of a wider set of actors in the sense of "incrementalism with a perspective" in planning (Ganser et al. 1993; Knapp et al. 2004), to be competitive it should rest on a new combination of local traditions (e.g. industrial heritage) and global trends (e.g. growing consumption of non-material and unique goods and services) (Hospers 2005; Koutský et al. 2011). However, the resulting industrial heritage tourism, which is a quite frequent example of a new combination used for restructuring (Hospers 2002), cannot alone rejuvenate the local economy. Rather it can be employed as a complementary measure (ibid; Harfst 2015) to a more holistic regeneration strategy as outlined by Agueda (2014).

While some scholars argued for primacy of institutional change in restructuring (e.g. Schamp 2000), others emphasized rather concentration on the built environment (Boschma \& Lambooy 1999). For example Agueda (2014) noted that successful holistic restructuring strategies often focus on: (i) brownfields regeneration, with the most valuable industrial heritage utilisation for tourism, whereas the majority of them is utilised for city inhabitants such as parks and other community services; (ii) affordable housing development and simultaneous social diversification of decaying districts; (iii) public transport development and upgrading of old networks (such as railway) so as to connect new development projects and accommodate city's new needs; (iv) diversification of the economic base for greater resilience to structural crises, while these new economic activities are often placed in regenerated industrial heritage buildings.

\section{Industrial heritage and Industrial Culture}

According to Rautenberg (2012), heritage is a socially constructed notion about a set of features of the past that should be utilised. However, he contends that what is to be included in "heritage' and how it should be utilised, is a matter of negotiation among different sorts of (social, economic and political) actors and subject to change over time. Harfst (2015) conceptualized industrial heritage distinguishing tangible (e.g. architectonic or technological heritage, infrastructure, production facilities and housing) and intangible (e.g. events, traditions and identity) features. The similar concept of Industrial Culture (Harfst et al. 2016) as well takes into account both of the dimensions, but puts emphasis on the intangible assets of the industrial past (skills, mind-sets and attitudes) for development of new branches of industry (see e.g. Klepper 2002; Boschma \& Wenting 2007). This paper does not exclude the notion of Industrial Culture from the analysis, but given our focus on physical structures, we prefer to use the narrower concept of industrial heritage. We understand industrial heritage both as tangible physical structures and intangible mental constructs (images, symbols, meanings, aesthetics) attached to the built form. Therefore, the next section will first discuss potential constraints and benefits for reuse of tangible industrial heritage, then will move on to intangible heritage.

Even though usually located in the inner city, former industrial sites are often not easily accessible due to geographical location, transport accessibility and lowered passability (Mommaas 2004; Fran- 
tál et al. 2013; Novosák et al. 2013). In the process of deindustrialisation, cities often suffer from economic decline, which is reflected in a lack of demand for vacant properties, and on the other hand, in an oversupply of these vacant properties resulting in a weak position on real-estate market (see Power et al. 2010). Specific position of brownfield sites in a city hierarchy is further exacerbated by frequent unclear ownership relations (Andres 2013). Paradoxically, this may be an opportunity for development of activities of various kinds; activities that are not restricted solely to market impetus (see e.g. Joo \& Park 2016). Therefore, otherwise unfavourable structural conditions imposed on the sites by deindustrialisation may on one hand constitute an advantage for some specific reuses and, at the same time, a disadvantage for others. However, the reuse of these sites (regarding all types of reuses) is often hindered by high decontamination costs, fragmented (intricate) ownership structure, a lack of vision, and, especially by potential investors, heritage protection is often seen as a constraint for development (Andres 2011; Novosák et al. 2013; Jigoria-Oprea \& Popa 2017).

The following section points to symbolic aspects of tangible heritage and its potential for reuse. Previously, "former industrial complexes symbolised an outdated era to be erased from the local collective memory (...) Thus, the complexes were demolished to give way to the 'modern' service-oriented city" (Mommaas 2004:512). Now the attitude towards these buildings changed along with symbols attached to it and it became a source to promote (Agueda 2014). As cities are increasingly dependent on their own (endogenous) resources, Hospers (2002) argued that industrial landscape might be used as a local asset that makes a difference in a global competition for tourists. And furthermore, with structural changes of the economy, it may be an opportunity to accommodate increasing demands for (leisure and recreational) services. As Rautenberg (2012) showed, however, the utilisation of industrial heritage for tourism is underpinned by a 'mythification' of labour and worker's culture. Although this transformation of a local industrial identity may be opposed by workers themselves, it is "probably the price to pay for sharing that kind of heritage with a large public" (Rautenberg 2012:523). Industrial buildings are interesting to people because of "unusual character" of its "purpose-built infrastructure" (Bujok et al. 2015). It may appeal to older generations out of nostalgia and to younger generation for its novelty (Hospers 2002; Jigoria-Oprea \& Popa 2017). Moreover, especially the young are nowadays losing touch with manufacturing, and thus contact with indus- trial monuments might provide them "the lessons about (...) inventiveness and creativity of our predecessors" (Bujok et al. 2015:83). Paradoxically, industrial heritage and its aesthetics of dereliction now often attract creative people (artists, designers, architects etc.), who set their studios in them (Hutton 2006; Whiting \& Hannam 2017), and so may contribute to development of "modern serviceoriented city" (cf. Mommaas 2004 above). According to research by Martinát et al. (2014:61), 90\% of visitors to regenerated brownfields find them aesthetically appealing. However, the "attractiveness of these sites as former brownfields is not so astonishing to attract crowds of tourists. It seems that the necessary precondition to attract tourists is to reasonably priced and quality services".

\section{Ostrava}

The city of Ostrava is in terms of its population (290 450 inhabitants in 2018, ČSÚ 2018, see Fig. 1) the third largest city in Czechia and the core of the Ostrava agglomeration, which emerged in process of industrialisation in the 19th and 20th century (Hruška-Tvrdý et al. 2012). The development of Ostrava is inherently connected to heavy industry and resource exploitation (mining of hard coal, metallurgy, chemical industry and processing industry).

Moschelesová (1924:570) expressively described the region at the beginning of the 20th century as follows: "Dark smoke clouds hang over the landscape, heaps of slag disfigure the ground, a hundred towering chimneys proclaim the entry into the manufacturing region of the Ostrava coal field". In 1980s, Ostrava generated some 17\% of Czechoslovak coal mining output, $65 \%$ of coke production, $40 \%$ of steel production and $45 \%$ of crude iron (Przybylová et al. 2013). Since 1989, in connection with the transition to market economy, Ostrava has been struggling with deindustrialisation and loss of jobs in industry. To give an example, in 1989, Ostrava fuel industry (including both mining and coking) employed 24000 people. After coal mining termination (1994), there were 1300 employees left in 2010 (ibid). Due to deindustrialisation, $8.4 \%$ of the total area of Ostrava is considered to be brownfields (Kunc et al. 2014). The urban structure of the city is characterized by fragmentation and polycentricity, which is a consequence of how Ostrava has evolved over time and expanded. That is by the gradual integrating of the surrounding communities into the structure of the growing city (), as well as the spa- 


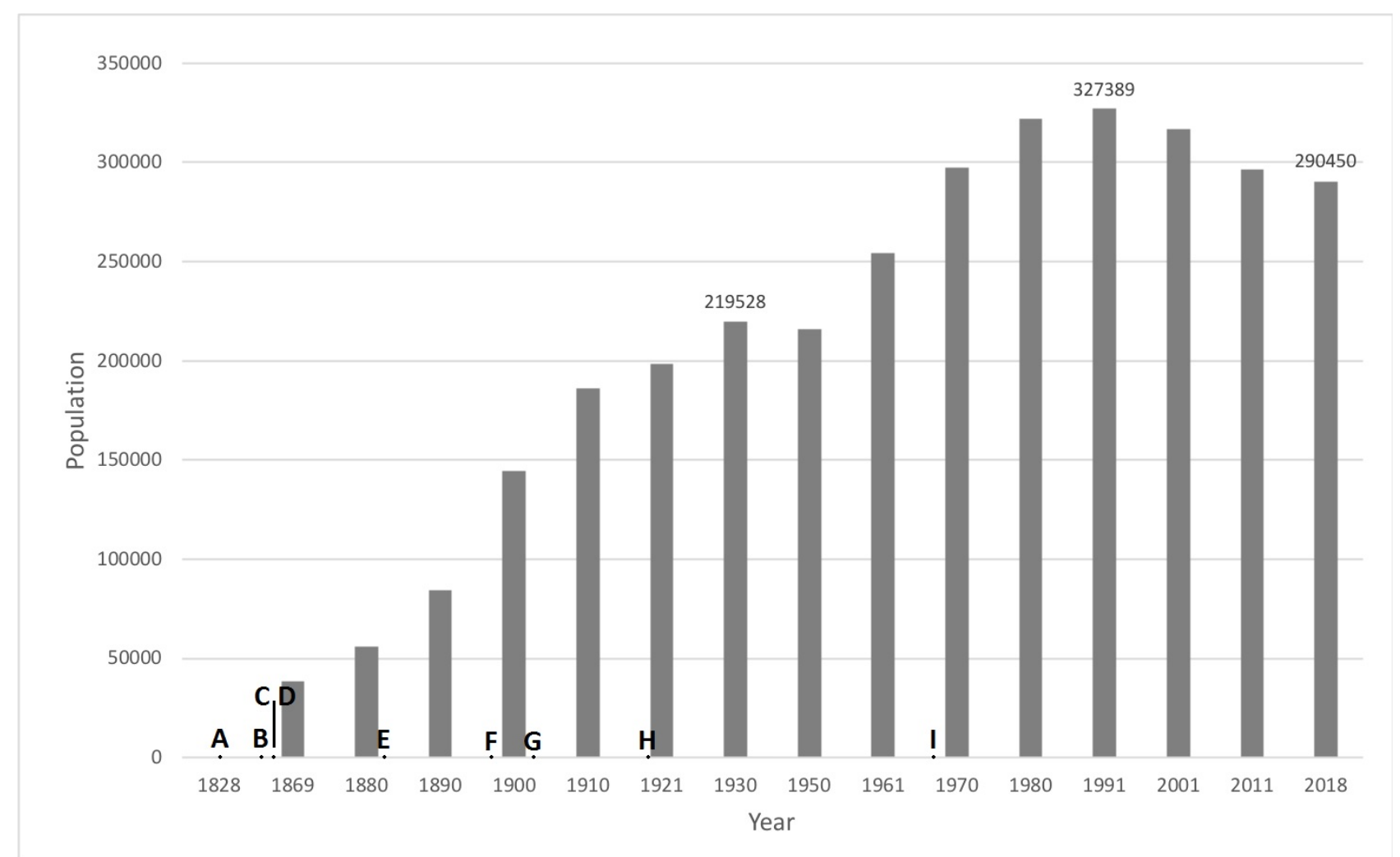

Fig. 1 Population change in Ostrava and timeline of selected cases, (A) Lower Vítkovice area, (B) Michal Mine, (C) Mining Railway, (D) Coking plant Karolina, (E) Gable colony, (F) Alexander Mine, (G) Triple Hall Karolina, (H) Ema slag heap, (I) Vítkovice railway station (source: Alexandr Nováček, ČSÚ))

tial fragmentation due to large industrial areas. To put it succinctly, industrialisation preceded urbanisation (Rumpel \& Slach 2012; Duží \& Jakubínský 2013). Afterwards, socialist planners decided to concentrate construction at a considerable distance from the historical centre in order to exploit coal reserves under centre and separate a residential function from air-polluting industry (Prokop 2006). In other words, residents were displaced to allow industrial growth. The two new-built districts of Ostrava-Jih and Poruba housed more than 200,000 people by 1980 , thus outnumbering historical districts and leading to formation of "triple city" (comprising of inner city, Ostrava-Jih and Poruba) (Zarecor 2018, see Fig. 2). Even though the target number of inhabitants has not been met (Danda 1988; ČSÚ 2013), the urban structures were built accordingly to the plan.

Decline in traditional industries had severe impact on the image and identity of the city. This crisis led first to rejecting of industrial heritage and attempts of policymakers to create an alternative image connected to greenery (Rumpel \& Slach 2012; Sucháček \& Herot 2015). To illustrate this, a member of the Ostrava municipality stated in 2001, on the account of Lower Vítkovice Area (see below; Duží \& Jakubínský 2013:61): "It is a heap of scrap. In the centre of the city ruins remain. It is an embarrassment for the city". In line with this view, the owner of this vast industrial complex considered its demolition (Malík 2012). However, this attitude towards industrial heritage was already at this point in sharp contrast to the fact that a large proportion of Ostrava inhabitants connected this area to their identity (Duží \& Jakubínský 2013). The attempts to project alternative image failed, for the industrial past is deeply rooted in inhabitant's identity as well as in omnipresent urban structures (Sucháček \& Herot 2015).

Subsequently, approximately between 2007-2009, the industrial past became incorporated in the official image and vision of Ostrava's future (see ibid; Bosák 2016). The main reason for acceptance of industrial heritage in municipality was tied to reconsideration of the city position in the context of the global economic crisis of 2008 and to the need to rest on endogenous resources, while we should not underestimate inspiration from abroad (see Slach et al. 2011; Marková \& Slach 2013). 


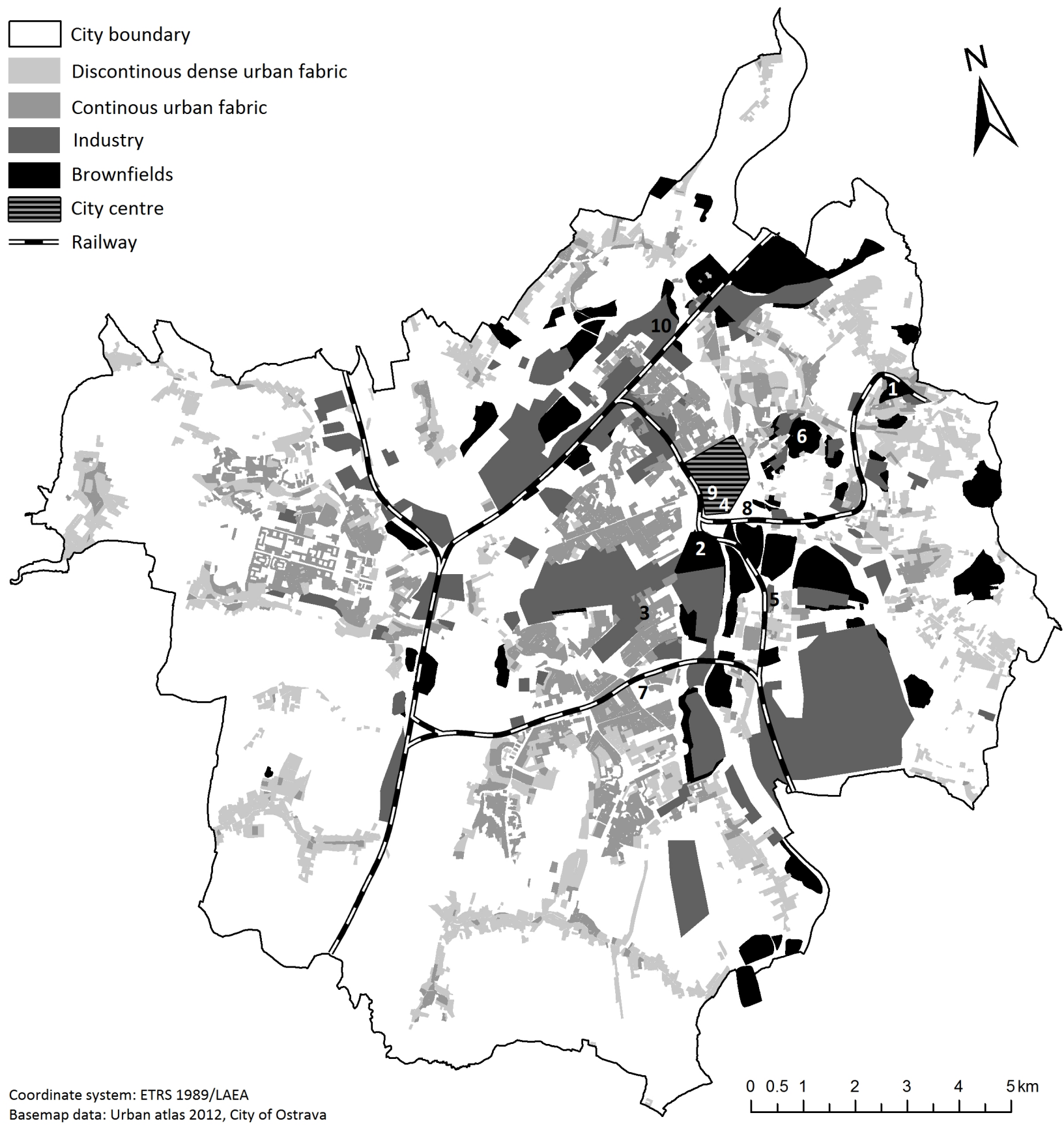

Fig. 2 Urban structure of Ostrava in 2018 and selected study cases, (1) Michal mine, (2) Lower Vítkovice area, (3) Gable colony, (4) Triple Hall Karolina, (5) Alexander Mine, (6) Ema slag heap, (7) Vítkovice railway station, (8) Mining Railway, (9) Shopping center New Karolina, (10) Coking plant Svoboda (source: Alexandr Nováček) 
Although, there is a tendency to utilise industrial heritage in a positive sense, the negative consequences still override positive ones, which is reflected in unfavourable external image. As Tödtling et al. (2013:196) wrote, "bad image as an old industrial region and the rather poor quality of the natural and built environment" results in low attractivity "to highly qualified people" and consequently "lack of the highest-quality human resources", which hinders further growth of knowledge intensive services such as ICT (ibid).

\section{Selection of cases}

In line with Harfst (2015:220), we have chosen examples"to illustrate the range of different utilisations possible, along with the problems encountered." Therefore, it is not to be understood as an all encompassing account of the issue. We would like to concede that what is considered here either an asset or a barrier is a matter of evaluation in locally specific context. All of the presented remainders of the industrial past are assets and barriers at the same time, while utilisation of some is more challenging than of others.

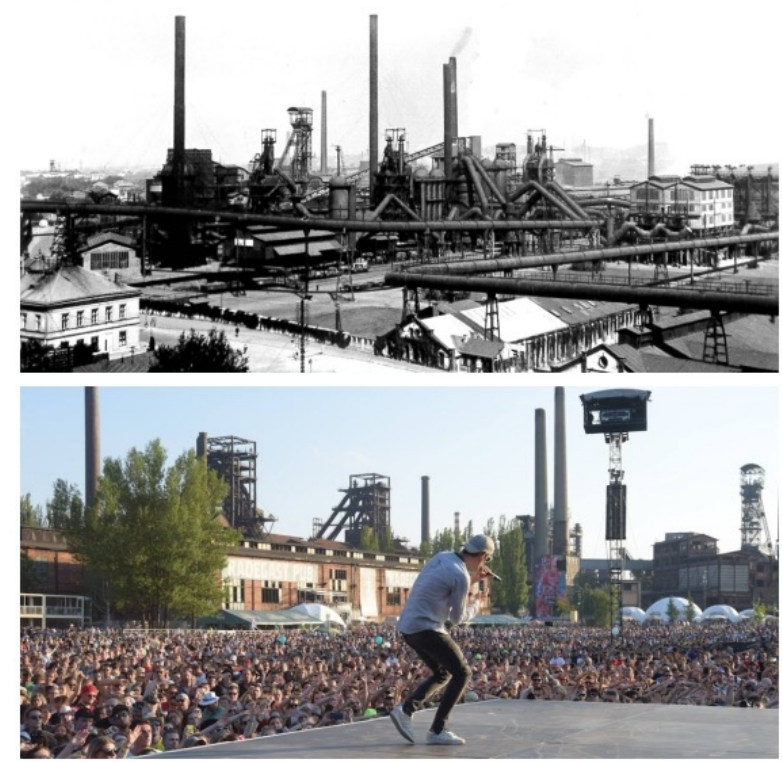

Fig. 3 Lower Vítkovice Area in 1930 and in 2017 during Colours of Ostrava festival (source: Durczak 2015; Yvette Stránská 2017)

To give an example, air pollution from industrial plants would demand a lot of effort to make advantage out of it, however, the intimate local knowl- edge about implementation of environmental technologies may lead to technological specialisation on R\&D in this field (see e.g. Maggi 2004; Rehfeld 2006). Thus, what is presented here as a 'barrier' is a barrier only under recent social, economic and political circumstances. The examples are structured in thematic groups regarding their new use, meaning or significance, to illustrate the range of new combinations (Hospers 2005) and different approaches on a scale from interventionism to opportunism (see Andres 2013) in industrial heritage utilisation. First, we will focus on utilisation of features and characteristics of industrial heritage for new purposes. Second, we will present examples of old structures originally created for needs of industry, which hinder development of the post-industrial city. Examples are situated in the inner city or neighbouring with it, although, we would like to emphasize that their impact is most often city-wide (the study area and selected cases are shown in the Fig. 2).

\section{Results}

\subsection{Industrial heritage tourism}

Michal Mine is situated in periphery of Ostrava and operated between 1851 and 1994. One year after its closing it became a protected cultural heritage site. The conservation of all buildings, machines and even miners' belongings proceeded according to the concept of the 'last working day' inspired by Essen's Zollveiner Mine. On guided tours, visitors are, besides the history of the mine and mining technology, presented the everyday life of miners. Emphasis is put on authentic experience of the patina-covered environment. Part of the tours is focused on the school children audience, were the hands-on approach and interactive learning are even more pronounced. The aim is to build a relationship to cultural-historical heritage (Kudelová 2017).

Lower Vítkovice Area (see Fig. 3) as part of a large industrial zone (150 ha) is situated within walking distance from the city centre. The history of the site started with the establishment of the first iron works in Ostrava in 1828. The uniqueness of the area rests, not only in pioneering industrialisation, but as well in subsequent creation of technology flow of coal, coke and iron, run by a single company, later followed by engineering. 

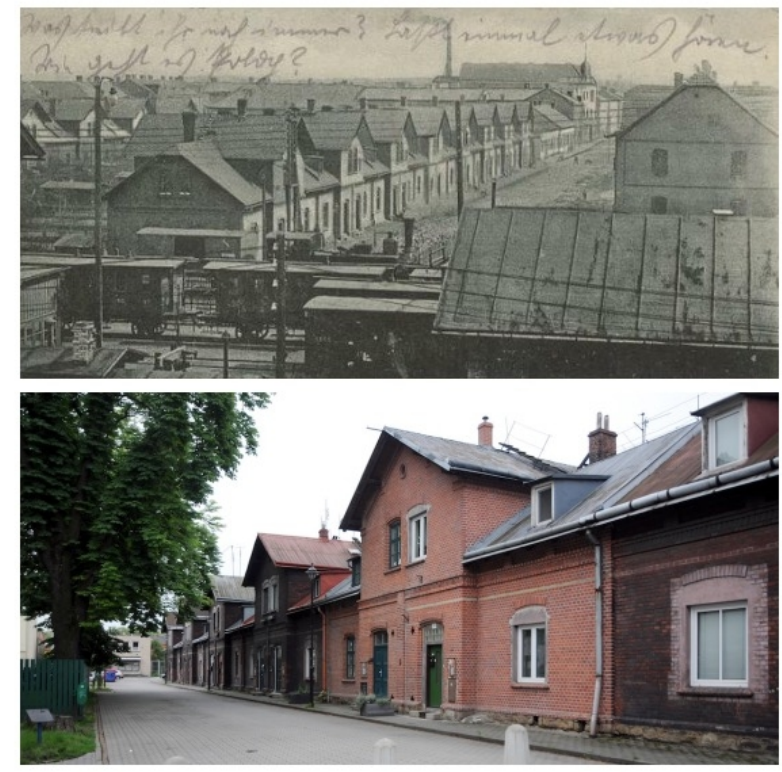

Fig. 4 Gable colony at the beginning 20th century and in 2016 (source: OstravaBlog.cz)

After closure of the adjacent Hlubina Mine in 1992, and blast furnaces in 1998, the oldest part (50 ha) became listed heritage monument, while engineering continued its operation (Tejzr 2007; Bujok et al. 2015). After a large-scale redevelopment, the heritage area was opened to public in 2012. While some buildings were reused for cultural, congress, educational, sport and entertainment functions, others stand only for demonstration of the technology process (from extraction of natural resource to a final product) on guided tours (Pavliňák 2012).

In 2016 the number of visitors to Lower Vítkovice Area and Landek Park (the regional museum of mining in Ostrava) combined amounted to 1.3 million. Therefore, it stands out as the most visited tourist destination outside of Prague capital (CzechTourism 2017). This success owes much to newly created attractive services (cf. Martinát et al. 2014) and smart rebranding of the area (cf. Koutský et al. 2011). These two aspects make the main difference from much less visited Michal Mine. However, the large industrial buildings, which contain the new functions, demand heavy public subsidies for operation costs such as utilities and maintenance (Bosák 2016).

\subsection{Workers' colonies as popular affordable housing}

When investigating the industrial heritage of Ostrava, we should not omit town-building activities of industrial enterprises. Throughout the history of Ostrava, almost 100 workers' colonies were established, while only about 30 of them have been preserved up to this day (Kuchtová 2011). While some of them became "urban brownfields" (Gargos \& Grulich 2009), others are used until now, such as the Vítkovice district. The expansion of production of Vítkovice company persuaded the then director to build housing and amenities for its workers, forming a new urbanistic concept of the whole district. He followed philosophy that the quality of workers' lives had to be improved in order to increase the production (Przybylová et al. 2013). One of the most significant (as evidenced by its heritage protection) housing projects is the so-called "Gable Colony" (Štítová kolonie) (see Fig. 4), built between 1883-1885. It consists of 32 double-storeyed houses, characteristic for its unstained red bricks facades, which supports the local genius loci. Originally, it represented simple and affordable housing for workers, but given the recent trend of a declining household size, it has become very popular for certain groups. Positive development is evidenced by the gradual renovation of buildings.

\subsection{Industrial heritage used for community services}

In the vicinity of the historical centre, there are some buildings after their redevelopment jointly known as Triple Hall Karolina (Trojhalí Karolina) (see Fig. 5).
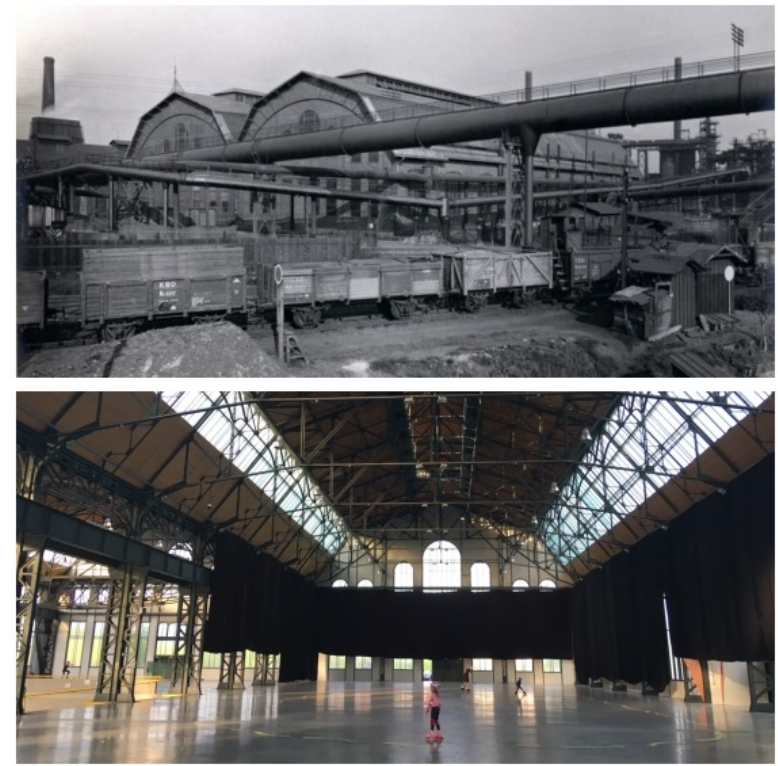

Fig. 5 Triple hall in operation and as roofed square (source: Trojhali.cz, Alexandr Nováček 2018) 
In fact, they consist of two buildings, a former power plant and double-nave energy central (Pavliňák 2012). They were built in the beginning of the 20th century and served for the Karolina coking plant. After demolition of the coking plant and other industrial plants, they remain the last reminder of the industrial history of the place and are now listed heritage monuments (Pavliňák 2012).

After redevelopment in 2014, the former power plant (1 $200 \mathrm{~m}^{2}$ ) functions as a playing field for various sports and the energy central $\left(4500 \mathrm{~m}^{2}\right)$ as a 'roofed square' for sports and culture (Rumpel \& Slach 2012). The concept of the 'roofed square' was supposed to, according to the architect, accommodate the greatest possible diversity of activities, as a traditional public space. However, some authors argue, it cannot function so, since the place is quite isolated from rest of the city (i.e. in contrast to centrality of a square). It can be viewed as a symptomatic example of a former industrial site in a central location and, at the same time, not easily accessible (cf. Mommaas 2004).
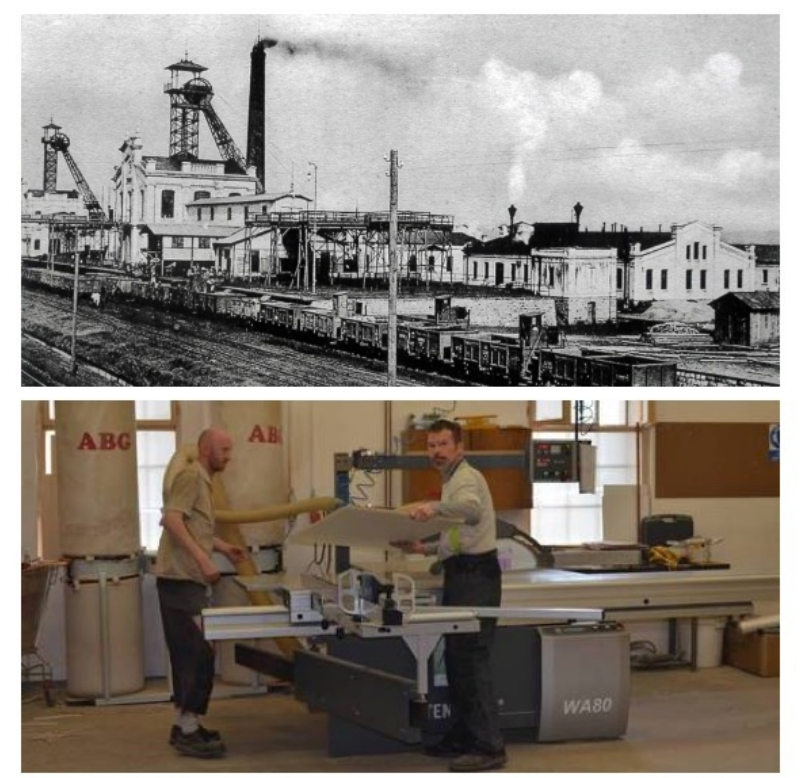

Fig. 6 Alexander mine in operation and sheltered cabinetmaker workshop (source: Durczak 2015; Charita sv. Alexandra)

Unlike the abovementioned mines, buildings of Alexander Mine (see Fig. 6) located in an inner city district of Ostrava now supports integration of local marginalized groups to the majority society. It was built in a neo-baroque architectural style in 1896 and operated until 1992. Later, in 2001, it became a protected heritage monument, and it was only reconstructed in 2016, ac- cording to the original form of buildings in 1901 . While newly reconstructed objects are waiting for a new use (Chřibek \& Radová 2016; Svoboda 2016), another three buildings (reconstructed earlier) are in use by a charity. It runs a sheltered accommodation for persons with mental disorders and workshops for physically handicapped, who could not find jobs on the labour market. The workshop products try to be competitive on the market and income from selling them covers part of their expenses (Folta 2015). Thus, it can be considered a social enterprise, which attempts to fill a gap in social services after partial retreat from welfare state politics (cf. Gidron \& Monnickendam-Givon 2017).

\subsection{Industrial landscape as opportunity for recreation}

Although inhabitants of Ostrava enjoy the proximity of the mountain range Beskydy (approximately 20 kilometres from Ostrava), there are more than 40 slag heaps located right in the city as a consequence of mining (Havrlant 1980), which can be also used for recreation. One of the most popular is Ema slag heap (see Fig. 7), located less than 1.5 kilometre from the city centre. It has been dubbed the "Ostrava Volcano" for it's a dome-like shape and the fact that underneath surface coal remnants are still burning. This was the reason for leaving the slag heap to spontaneous succession, resulting in the emergence of urban wilderness.

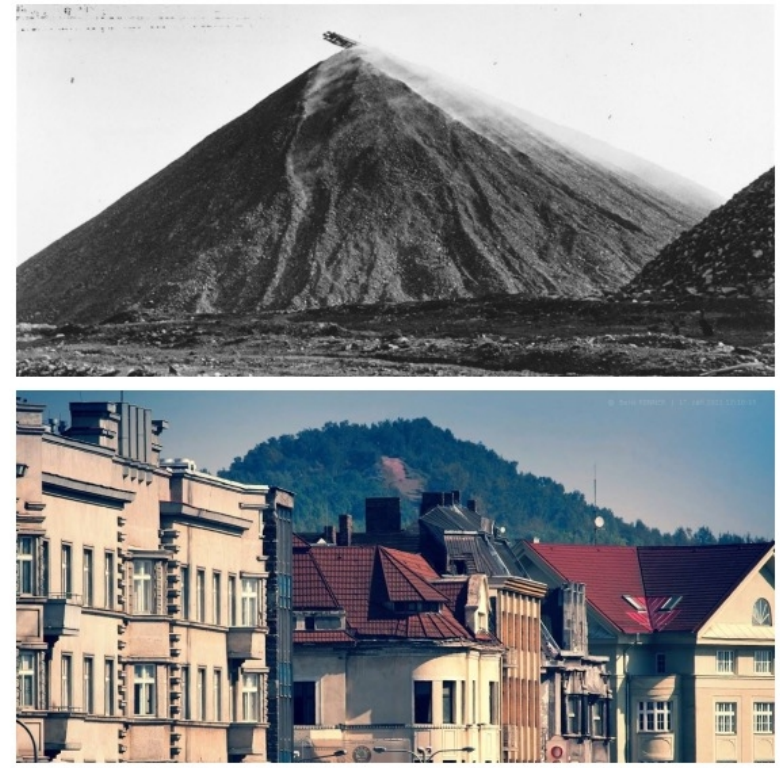

Fig. 7 Ema slag heap in 1962 and 2014 (source: Archiv MfD, Boris Renner 2014) 
Although the burning coal contributes to air pollution (Pertile et al. 2017), the higher average temperatures have led to occurrence of various thermophilic plant and animal species (Niemiec et al. 2017), thus enhancing biodiversity. Due to thermal activity, there was no trespassing in the past but entry is now allowed at one's own risk. Subsequently, it became a very popular and cheap option for everyday recreation and sports activities for Ostrava inhabitants (cf. Franz et. al. 2008). This case of industrial heritage reuse demonstrates that, in certain cases, almost effortless and cost-free management is sufficient for emergence of a new use (see Rink 2009), which fits global trends (i.e. sports and healthy lifestyle). However, the only significant variable is time; for such a natural change it takes decades.

\subsection{Transportation infrastructure as an asset and a barrier}

In 1970, Carter considered the passenger rail from city centre to Vítkovice, which has been built in half of the 19th century, to be one of the busiest in the city due to concentration of large industrial enterprises in the district, particularly the Vítkovice company. The significance was thereafter reflected in emphasis on high-quality modernist architecture, technological innovations and artistic decorations of a railway station building (see Fig. 8), constructed in 1967 (Strakoš 2012). The frequency of passengers kept growing until 1987, when the Vítkovice company employed 36000 workers. At the same time, the number of the Vitkovice district's inhabitants decreased from its peak in 1921 (27 400) to less than 17000 in 1961 due to the spread of industrial plants at the expense of a residential area (Kovár 2012), which further increased the need to commute. The station was also used for long-distance rail connections by inhabitants of Ostrava-Jih district, partly built for Vítkovice workers (Danda 1988). The dimensions of the station were planned for turnover of 3500 commuting workers and another 7000 passengers per hour (nadrazivitkovice.cz). The importance of the station declined after 1989 as an effect of deindustrialisation of the district, as evidenced by further decreasing number of Vítkovice employees (1987: 35 000, 2016: 5 500, Czech Statistical Office 1987, patriotmagazin.cz), but also due to continuing outmigration (only 7,000 inhabitants in 2011, Czech Statistical Office 2013) and redirection of connections to the Ostrava main railway station (nadrazivitkovice.cz). Since then, the underused building started to decay, but attempts to list the building as a heritage monument (for its architectural qualities) eventually failed (for supposed moral obsolescence). Since 2015, the building has been maintained by volunteers, but is in the need of extensive reconstruction. Among suggested reuses were, for example, a museum of railways and a gymnasium (for physical exercise), but have been rejected so far due to their high cost (Strakoš 2012). What the future of this immense building will look like remains to be seen, but it stands as an example of infrastructure built for an ever-expanding economic base of the industrial city.

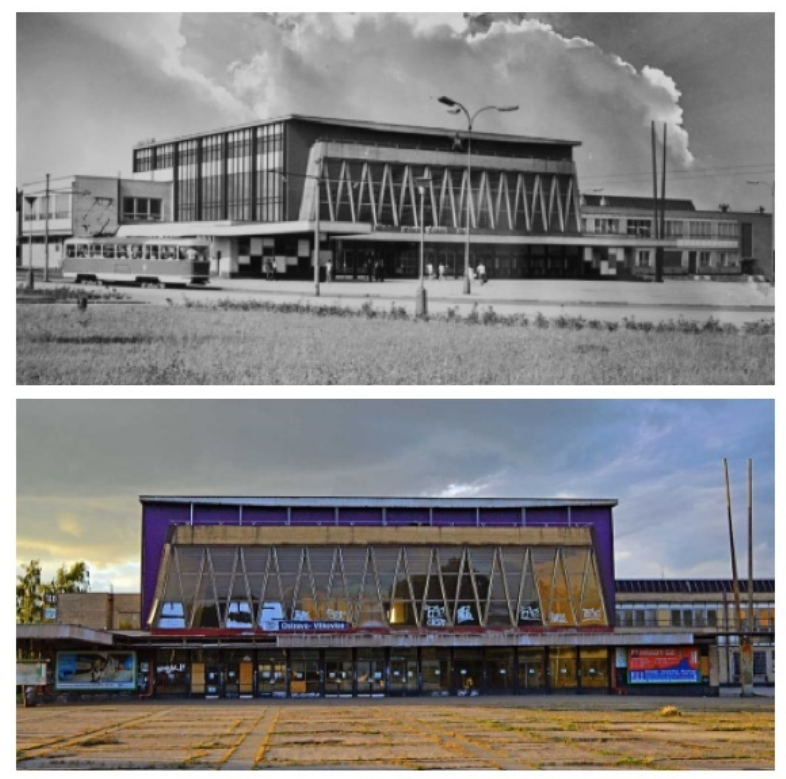

Fig. 8 Vítkovice railway station in 1971 and 2015 (source: Ostravské muzeum; Petr Přendík 2015)

Between the New Karolina shopping mall (see bellow) and Lower Vítkovice Area is located a freight trail known as The Mining Railway (see Fig. 2). It was built in 1858 (Frühwirt 1974) and served for transport of hard coal to the ironworks and waste rock (gangue) to slag heaps. After termination of mining in Ostrava in the 1990s, it lost its significance. Now it is partially used by AWT company as access to its depot nearby the closed Zárubek Mine and for transport of coal from still active (albeit slumping) mines near the town of Karviná to ArcellorMittal Ironworks (Vrtek 2016). The freight trail is now regarded by the city authorities as a barrier to access from the city centre to the biggest tourist attraction of the city. In course of urban planning, relaying of the trail came into consideration several times (by developers, see ECE \& Passerinvest 2006; spatial planners, see UDI MORAVA, 2011; municipality spatial planners, see Ostrava 2014; an architect, see 
Vrtek 2016) as it hinders positive spill over effects of regeneration between the two greatest investments in the built environment (with significance for the entire city) from the last decade (see Nováček 2016; Bosák 2016). Recently, initiated by an Ostrava citizen, the city authorities are contemplating the utilisation of large part of the freight trail, which is connected to the passenger railway network, for transport between major tourist attractions (Lower Vítkovice Area, zoological garden and Michal Mine) (fajnOVA 2018). This example shows that industrial heritage is a barrier and an asset at the same time and which aspect prevails depends on range of actors included in planning, but most importantly, on the imagination of the actors.

\subsection{Mixing of incompatible functions in urban structure}

On the industrial site Karolina a mine was first built (1842), followed by a coking plant (1858) and ironworks (1871). Due to the later development of the urban structure, it happened to be located in the vicinity of the city centre with the most representative institutions, such as a department store, banks and hotels.
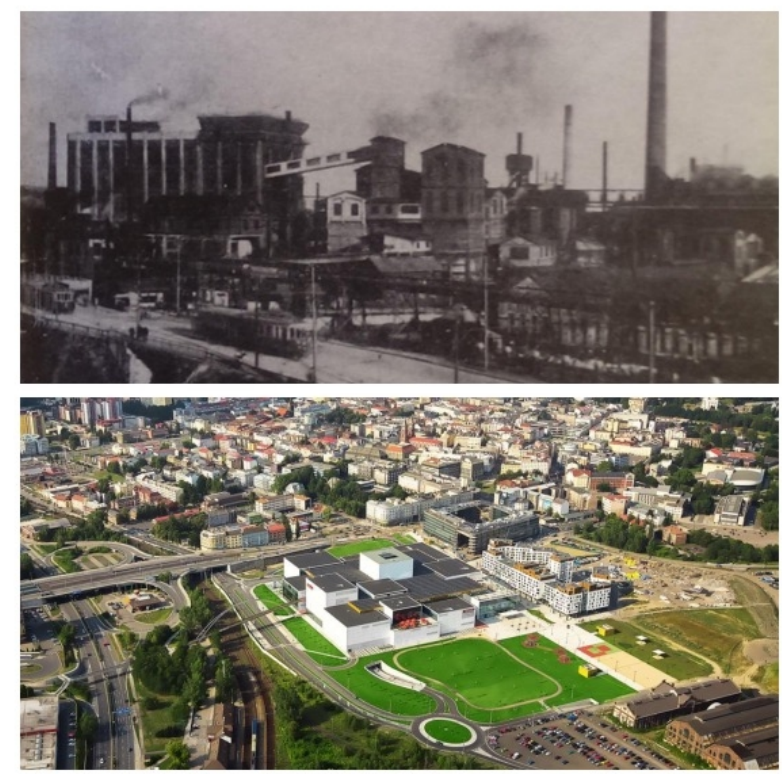

Fig. 9 Coking plant Karolina in operation and shopping center New Karolina in 2010 (source: Msstavby.cz, Multi development)

In 1964 it was decided that due to the "poor state of the air" the industrial plants would be closed, but the demolition was postponed until 1970s and 1980s, while the decontamination of this brown- field was not completed until 1997. The plans to enlarge city centre on the brownfield existed already in the 1960s but were delayed until 2012, when the developer project was opened. It includes the New Karolina shopping centre (see Fig. 9), with $58000 \mathrm{~m}^{2}$ and more than 240 retail units, residential buildings and offices.

But this reuse of brownfield did not enlarged city centre, but happened to be in competition with it, as evidenced by long-term retail unit vacancies and spiralling decline in quality of retail mix in the city centre (see Nováček et al. 2018). We can understand the preference of customers also as a consequence of long-term neglect of public space in city centre, which has its roots in urbanistic plans from socialism determined by needs of growing industry (see above).

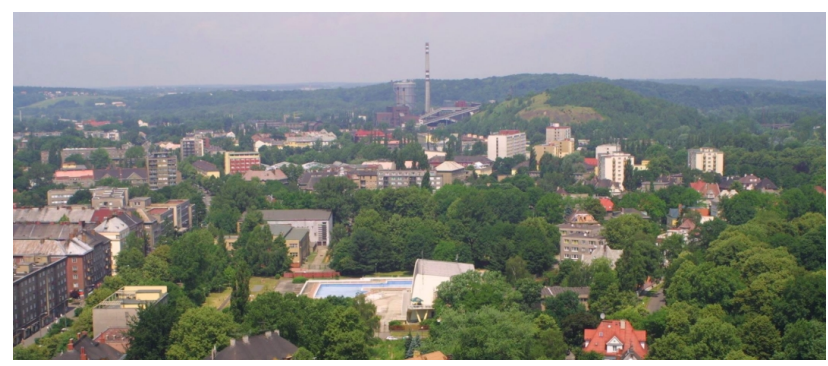

Fig. 10 Coking plant Svoboda (source: Petr Rumpel 2004)

It is paradoxical that while socialist planners could terminate the Karolina coking plant, the recent municipality officials, who fight Ostrava's bad image, leave another coking plant called Svoboda (see Fig. 10) in operation in the Prrívoz district. The persistent bad image of old industrial city is thus strengthened, as the limit values set for benzo(a)pyrene and other pollutants produced by coking with carcinogenic effects are violated (Havrlant 2012). Since this effect of industrial production is against the global trend of a growing environmental consciousness in large groups of the population (Inglehart 1995), it is particularly damaging for the city.

\section{Conclusion}

We have shown that the present of an old industrial city, such as Ostrava, is deeply encoded in the built environment and image of its industrial past. These structures are major constraints for urban restructuring, and it takes 'imaginative thinking' (JigoriaOprea \& Popa 2017) to overcome it and utilise its intrinsic features for the new needs of post-industrial 
development. Furthermore, we showed that industrial heritage is a social construct evolving according to goals of local actors, which are, however, influenced by external structural conditions. Our paper suggests that industrial heritage is important point of self-reference. While remnants of the industrial past from the 19th century have been included in 'heritage' by local policymakers, remnants of the socialist era industrialisation are still rather rejected or ignored, except for some examples such as the Poruba district (Zarecor \& Špačková 2012). This claim is supported by comparison of the six 19th century industrial buildings that became protected heritage monuments and the one from the socialist period (Vítkovice railway station, see Fig. 1), whose protection is asserted by experts and activists and opposed by the general public and public administration on different scales (Strakoš 2012). We suggest that this rejection may be due to intangible features of the building connected to the origin in the socialist period, for "[t]he socialist era is represented" in people's mindsets "as an aberration, a mistake to be forgotten" (Young \& Kaczmarek 2008, p. 64), thus these identities may pose a constraint for reuse of the building. However, Young and Kaczmarek (2008) and Murzyn-Kupisz and Gwosdz (2011) documented on Polish cases that industrial heritage from the socialist period may be utilised, while removing from it its socialist past or pointing only to selected features of this period. Whether these cultural aspects of industrial heritage hold today as a decisive point for industrial heritage rejection, or acceptance and reuse, however, calls for further testing. It might stand as case in point that not only physical peculiarities of tangible industrial heritage might be a constraint (or an asset) for utilisation, but also its intangible features. What the future holds for Ostrava industrial heritage from the second wave of industrialisation remains to be seen. And so for any other industrial heritage, the utilisation of which, is in hands of local actors. Although we have documented a number of successful reuses, the planning process resembles rather incrementalism without perspective (Rumpel \& Slach 2012, emphasis added), for they are only isolated projects without the framework of a joint vision, which reduces their incorporation in the city organism (cf. Ganser et al. 1993). So far, the projects were most often forwarded by private and non-profit actors. The rather limited role played by the public sector should be viewed in the context of the weak position of the planning and public sector in post-socialist cities (Rink et al. 2014). While the composition of actors involved is significant for utilisation of particular industrial heritage features, the leadership of the public sector is es- sential for maximisation of industrial heritage reuse impact on restructuring of the whole city and even more so in resolving of the negative impact of industrial city evolution (i.e. mixing of incompatible functions in urban structure) on future post-industrial city development.

\section{Acknowledgements}

The authors acknowledge support from the Czech Science Foundation through a research grant 'Paths development in traditional industries in old industrial regions in Czechia: governance, actors, institutions and leadership' (18-11299S). We would like to thank two reviewers and editors of this special issue for their helpful comments and suggestions. Any errors and omissions remain the authors' responsibility.

\section{References}

Agueda BF (2014) Urban restructuring in former industrial cities: urban planning strategies. Territory in movement. Journal of Geography and Planning 23-24: 3-14.

Andres L (2011) Alternative Initiatives, Cultural Intermediaries and Urban Regeneration: the Case of La Friche (Marseille). European Planning Studies 19(5): 795-811.

Andres L (2013) Differential Spaces, Power Hierarchy and Collaborative Planning: A Critique of the Role of Temporary Uses in Shaping and Making Places. Urban Studies 50(4): 759-775.

Bosák V (2016) Role kultury v regeneraci brownfields: př́padová studie Dolní oblasti Vítkovic. Ostravská univerzita, Ostrava.

Boschma R, Lambooy J (1999) The prospects of an adjustment policy based on collective learning in old industrial regions. GeoJournal 49(4): 391-399.

Boschma RA, Wenting R (2007) The spatial evolution of the British automobile industry: Does location matter?. Industrial and corporate change 16(2): 213-238.

Bujok P, Klempa M, Jelinek J, Porzer M, Rodríguez González MA (2015) Industrial tourism in the context of the industrial heritage. GeoJournal of Tourism and Geosites 15(1): 81-93.

Carter F W (1970) Czechoslovakia's North Moravian region: a geographical appraisal. Revue Géographique de l'Est 10(1): $65-86$.

Chřibek L, Radová M (2016) V Ostravě vzniklo "hornické Versailles". Za necelých 8 milionů korun. Available online at: (http://www.ceskatelevize.cz/ct24/regiony/1961795-v-ostravevzniklo-hornicke-versailles-za-necelych-8-milionu-korun) (accessed on May 2018).

CzechTourism (2017) Návštěvnost turistických cílů 2016. Institut turismu. Available online at: (http://www.czechtourism.cz/getattachment/Institut-turismu/Marketingovyvyzkum/Infografiky/Navstevnost-turistickych-cilu-2016/NTC_2016) (accessed on May 2018).

Czech Statistical Office (1987) Pracovníci a mzdové fondy socialistického sektoru národního hospodářství (bez JZD) v krajích a okresech podle odvětví národního hospodářství v ČSR za rok 1987. Czech Statistical Office, Prague. Available online at: (https://ideas.repec.org/a/prg/jnlrst/v2009y2009i2id14p38-44.html) (accessed on June 2018). 
Czech Statistical Office (2013) Statistický lexikon obcí České republiky 2013. Czech Statistical Office, Prague.

Czech Statistical Office (2018) Population of municipalities. Czech Statistical Office, Prague.

Danda J (1988) Naše železniční nádraží. Nadas, Praha.

Duží B, Jakubínský J (2013) Brownfield dilemmas in the transformation of post-communist cities: A case study of Ostrava, Czech Republic. Human Geographies 7(2): 53-64.

ECE, Passerinvest (2006) Passerinvest a ECE představily svou vizi Karoliny v expresu Karolina, Available online at: (http://www.passerinvest.cz/cs/tiskove-zpravy/667?articleListvp-page =14) (accessed on May 2018).

FajnOVA (2018) Dopravní obslužnost ZOO, Available online at: (http://fajnova.cz/projekt/dopravni-obsluznost-zoo/) (accessed on May 2018).

Folta P (2015) Výroční zpráva. Rok 2015. Available online at: (http://charita-sv-alexandra.cz/res/archive/021/002844.pdf). (accessed on May 2018).

Franz M, Güles O, Prey G (2008) Place-making and 'green'reuses of brownfields in the ruhr. Tijdschrift voor Economische en Sociale Geografie 99(3): 316-328.

Frühwirt J (1974) Koňská dráha z Vítkovických železáren na nádraží v Přívoze v letech 1856-1858. In: Ostrava. Sborník př́spěvků k dějinám a výstavbě města. Ostrava, pp. 191-209.

Ganser K, Siebel W, Sielverts T (1993) Die Planungsstrategie der IBA Emscher Park. Eine Annäherung. RaumPlanung 61: 112-118.

Gargos I, Grulich T (2009) Brownfieldy v české republice: koncepční podpora regenerace agenturou czechinvest. Urbanismus a územní rozvoj 12(6).

Gidron B, Monnickendam-Givon Y (2017) A social welfare perspective of market-oriented social enterprises. International Journal of Social Welfare, 26(2): 127-140.

Grabow B, Hollbach-Grömig B (1995) Weiche Standortfaktoren. Schriften des Deutschen Institut für Urbanistik Band, 89. Dt. Gemeindeverlag, Stuttgart-Berlin-Köln.

Hamm R, Wienert H (1990) Strukturelle Anpassung altindustrialisierter Regionen im internationalen Vergleich. Duncker \& Humbolt, Berlin.

Harfst J (2015) Utilizing the past: Valorizing post-mining potential in Central Europe. The Extractive Industries and Society 2(2): 217-224.

Harfst J, Pizzera J, Simic D (2016) Industrial heritage, cultural resources of current industries and creative pioneers-utilizing Industrial Culture in Central Europe. Journal for Geography 11(2): 47-56.

Havrlant M (1980) Geografie Severomoravského kraje. Pedagogická fakulta, Ostrava.

Havrlant J (2012) Problémy znečištění ovzduší v Moravskoslezském kraji. In: Havrlant J (ed.) Vybrané problémy rozvoje Moravskoslezského kraje. Ostravská univerzita, Ostrava, pp. 120-153.

Helbrecht I (2004) Bare geographies in knowledge societies-creative cities as text and piece of art: two eyes, one vision. Built environment 30(3): 194-203.

Hospers GJ (2002) Industrial Heritage Tourism and Regional Restructuring in the European Union. European Planning Studies 10(3): $397-404$.
Hospers GJ (2005) Best Practices and the Dilemma of Regional Cluster Policy in Europe. Tijdschrift voor Economische en Sociale Geografie 96(4): 452-457.

Hruška-Tvrdý L, Samiec M, Svobodník J, Matoláková R, Foldynová I (2012) Socioekonomický atlas Moravskoslezského kraje. Accendo - Centrum pro vědu a výzkum, Ostrava.

Hutton TA (2006) Spatiality, built form, and creative industry development in the inner city. Environment and Planning A 38(10): $1819-1841$.

Inglehart R (1995) Public support for environmental protection: Objective problems and subjective values in 43 societies. Political Science \& Politics 28(1): 57-72.

Jigoria-Oprea L, Popa N (2017) Industrial brownfields: An unsolved problem in post-socialist cities. A comparison between two mono industrial cities: Reşiţa (Romania) and Pančevo (Serbia). Urban Studies 54(12): 2719-2738.

Joo YM, Hoon Park S (2016) Overcoming Urban Growth Coalition: The Case of Culture-Led Urban Revitalization in Busan, South Korea. Urban Affairs Review 52(2): 1-25.

Kilper H (1999) Die Internationale Bauausstellung Emscher Park: Eine Studie zur Steuerungsproblematik komplexer Erneuerungsprozesse in einer alten Industrieregion. SpringerVerlag.

Klepper S (2002) The capabilities of new firms and the evolution of the US automobile industry. Industrial and corporate change 11(4): $645-666$.

Knapp W, Kunzmann KR, Schmitt P (2004) A cooperative spatial future for RheinRuhr. European Planning Studies 12(3): 323-349.

Koutský J, Slach O, Boruta, T (2011) Restructuring economies of old industrial regions-Local tradition, global trends. In: Scale of Globalization: Think Globally, Act Locally, Change Individually in the 21st Century. Conference Proceedings. University of Ostrava, Ostrava, pp. 166-173.

Kovář J (2010) Ostrava a Ostravsko v územně správní struktuře státu. In: Hruška-Tvrdý L, Illner M, Musil J, Keller J, Kovář J, Šotkovský I, Ivan I (eds.) Industriální město v postindustriální společnosti 1. díl. Printo, Ostrava.

Kovář J (2012) Ostrava a Ostravsko do poloviny 60. let minulého století. In: Hruška-Tvrdý L (ed.) Industriální město v postindustriální společnosti (2. Part - sousedství, komunity a lokality). Accendo - Centrum pro vědu a výzkum, Ostrava, pp. 56-72.

Kudelová M (2017) The Life and Work of Miners: Didactic Approaches of Three Mining Places of Memory in Education. Muzeum: Muzejní a vlastivědná práce 55(1): 28-37.

Kuchtová R (2011) Dělnické kolonie v Ostravě. Urbanismus a územní rozvoj 14(6): 11-15.

Kunc J, Martinát S, Tonev P, Frantál B (2014) Destiny of Urban Brownfields: Spatial patterns and perceived consequences of post-socialistic deindustrialization. Transylvanian Review of Administrative Sciences 41: 109-128.

Maggi C (2004) Strukturwandel und Strukturpolitik an Rhein und Ruhr: Schlüsselfaktoren und künftige Herausforderungen. In: Meyer-Stamer J, Maggi C, Giese M (eds.) Die Strukturkrise der Strukturpolitik. Verlag für Sozialwissenschaften, pp. 45-66.

Malík P (2012) Zhodnocení rozvoje území Dolní oblast Vítkovic. Ostravská univerzita, Ostrava.

Marková B, Slach O (2013) Governance kulturou tažené urbánní regenerace: Př́padová studie Černá louka v Ostravě. Sociální studia 10(4): 127-142.

Martin R (2010) Roepke Lecture in Economic Geography-Rethinking regional path dependence: beyond lock-in to evolution. Economic geography 86(1): 1-27. 
Martinát S, Krejčí T, Klusáček P, Dohnal T, Kunc J (2014) Brownfields and tourism: contributions and barriers from the point of view of tourists. In: Fialová J, Pernicová D (eds.) Proceedings of conference Public recreation and landscape protection-with man hand in hand?. Mendelova univerzita v Brně, Brno.

Mommaas H (2004) Cultural clusters and the post-industrial city: towards the remapping of urban cultural policy. Urban studies 41(3): 507-532.

Moschelesová J (1924) Natural regions of Czechoslovakia. Geographical Review 14(4): 561-575.

Nadrazivitkovice.cz Historie. Available online at: (http://www.nadrazivitkovice.cz/?page_id=84) (accessed on May 2018).

Murzyn-Kupisz M, Gwosdz K (2011) The changing identity of the Central European city: the case of Katowice. Journal of Historical Geography, 37(1): 113-126.

Nováček A (2016) Budoucnost městských center malých a středně velkých měst. Ostravská univerzita, Ostrava.

Nováček A, Slach O, Krtička, L (2018) Rozmístění maloobchodních jednotek v centrech velkých měst: případová studie Ostravy. In: Ženka J, Slach O (eds.) Rozmístění služeb v Česku. En Face, Ostrava, pp. 133-156.

Novosák J, Hájek O, Nekolová J, Bednář P (2013) The spatial pattern of brownfields and characteristics of redeveloped sites in the Ostrava metropolitan area (Czech Republic). Moravian Geographical Reports 21(2): 36-45.

Niemiec D, Duraj M, Xianfeng Ch, Marschalko M, Kubáč J (2017) Selected Black-Coal Mine Waste Dumps in the Ostrava-Karviná Region. In: World Multidisciplinary Earth Sciences Symposium. Conference Proceedings, IOP Publishing, Prague, pp. 1-7.

Ostrava (2014) Územně analytické podklady pro správní obvod statutárního města Ostravy. Aktualizace 2014, Available online at: (http://gisova.ostrava.cz/uzemne-analyticke-podklady/dokumenty/pruvodni_zprava_uap_2014.pdf) (accessed on May 2018).

Ostrava.cz (2018) Počet obyvatel ve správním obvodu statutárního města Ostravy, Available online at: (https://www.ostrava.cz/cs/urad/hledam-informace/aktualni-informace/pocetobyvatel-ve-spravnim-obvodu-statutarniho-mesta-ostravy) (accessed on May 2018).

Patriotmagazin.cz (2016) Strojírenská vítkovická skupina zeštíhlela o stovky zaměstnanců, Available online at: (http://www.patriotmagazin.cz/strojirenska-vitkovicka-skupina-zestihlela-ostovky-zamestnancu) (accessed on May 2018).

Pavliňák P (2012) Dolní Vítkovice dnes. Výtvarné centrum Chagall, Ostrava.

Pertile E, Surovka D, Sarčáková E, Božoš A (2017) Monitoring of Pollutants in an Active Mining Dump Ema, Czech Republic. Inzynieria Mineralna Journal of the Polish Mineral Enginerring Society. Polish Mineral Engineering Society, pp 45-50.

Power A, Plöger J, Winkler, A (2010) Phoenix cities: The fall and rise of great industrial cities. Policy Press, Bristol.

Prokop R (2006) Vývojové proměny postsocialistických měst Ostravska a Hornoslezského regionu v podmínkách transformace. Slezský ústav Slezského zemského muzea. Tilia, Šenov u Ostravy. Przybylová B, Barcuch A, Brňovják J, Daněk R, Glombíčková Š, Juřica M, Maňas V, Moravec Z, Rohlová E, Šerka J, Šústková H, Zezula M (2013) Ostrava: Dějiny moravských a slezských měst. Lidové noviny, Praha.

Rautenberg M (2012) Industrial heritage, regeneration of cities and public policies in the 1990s: elements of a French/British comparison. International Journal of Heritage Studies 18(5): 513-525.

Rehfeld D (2006) Kompetenzfeldwirtschaft im Ruhrgebiet. Zeitschrift für Wirtschaftsgeographie 50(1): 245-257.
Rink D (2009) Wilderness: The nature of urban shrinkage? The debate on urban restructuring and restoration in Eastern Germany. Nature and Culture 4(3): 275-292.

Rink D, Couch C, Haase A, Krzysztofik R, Nadolu B, Rumpel $P$ (2014) The governance of urban shrinkage in cities of postsocialist Europe: policies, strategies and actors. Urban Research \& Practice, 7(3): 258-277.

Rumpel P, Slach O (2012) Governance of shrinkage of the city of Ostrava. European Science and Art Publishing, Praha.

Schamp EW (2000) Vernetzte Produktion. Industriegeographie aus institutioneller Perspektive. Darmstadt.

Siebel W, Ibert O, Mayer H N (2001) Staatliche Organisation von Innovation: Die Planung des Unplanbaren unter widrigen Umständen durch einen unbegabten Akteur. Leviathan 29(4): 526-543.

Slach O, Rumpel P, Boruta T (2011) Transferable Impulses of IBA Emscher Park - Czech Perspective. In: Reicher Ch, Niemann L, Uttke A (eds.) Internationale Bauausstellung Emscher Park: Impulse lokal, regional, national, international. Klartext Verlag, Essen, pp. 210-220.

Strakoš M (2012) Architektura pozdního modernismu v ohrožení: Ostrava, Havířov, Frýdek-Místek... Protimluv (3): 14-20.

Sucháček J, Herot P (2015) Case F: The City of Ostrava - From Industrial Image to Industrial Image 2.0. In: Go F M, Lemmetyinen A, Hakala U (eds.) Harnessing Place Branding through Cultural Enterpreneurship. Palgrave Macmillan, Basingstoke, pp. $191-210$.

Svoboda T (2016) Ze staré šachty je zase zámek! Ostravský důl Alexander se připravuje na nový život, Available online at: (http://www.patriotmagazin.cz/ze-stare-sachty-jezase-8222-zamek-8220-ostravsky-dul-alexander-se-pripravujena-novy-zivot) (accesed on May 2018).

Tejzr L (2007) Vývoj technologie. In: Polášek M, Polášek R, Machotková J (eds.) Vítkovice Industria. EN FACE, Ostrava.

Tödtling F, Skokan K, Höglinger C, Rumpel P, Grillitsch M (2013) Innovation and knowledge sourcing of modern sectors in old industrial regions: comparing software firms in Moravia-Silesia and Upper Austria. European Urban and Regional Studies 20(2): 188-205.

UDI MORAVA (2011) Dopravně urbanistická studie - Hlubina. Available online at: (http://www.msstavby.cz/propojenidova-centra-ostravy-08-09-2015) (accessed on May 2018).

Vrtek T (2016) Územní studie rozvojového území Vítkovice Moravská Ostrava. Vysoké učení technické v Brně, Brno.

Whiting J, Hannam K (2017) 'The secret garden': Artists, bohemia and gentrification in the Ouseburn Valley, Newcastle upon Tyne, UK. European Urban and Regional Studies 24(3): 318-334.

Young C, Kaczmarek S (2008) The socialist past and postsocialist urban identity in Central and Eastern Europe: The case of Łódź, Poland. European Urban and Regional Studies, 15(1): 53-70.

Zarecor KE (2018) What Was So Socialist about the Socialist City? Second World Urbanity in Europe. Journal of Urban History 44(1): 95-117.

Zarecor KE, Špačková E (2012) Czech paneláks are disappearing, but the housing estates remain / České paneláky miznú, ale sídliská zostávajú. Architektúra \& urbanizmus 46(3-4): 289-301.

Ženka J, Pavlík A, Slach O (2017) Resilience of metropolitan, urban and rural regions: a Central European perspective. Geoscape 11(1): 25-40. 